\title{
Research on Lean Production Mode Evaluation of Railway
}

\author{
Li Sun ${ }^{1,}$, Chuang Yang ${ }^{1, b}$, Jiang Wei ${ }^{2}$ and Fengbin Jing $^{2}$ \\ ${ }^{1}$ School of Mechanical Engineering, Dalian Jiaotong University, Dalian 116028, China; \\ ${ }^{2}$ Technology Department of CRRC, Dalian Locomotive \& Rolling Stock Co.,Ltd, Dalian 116028, \\ China.

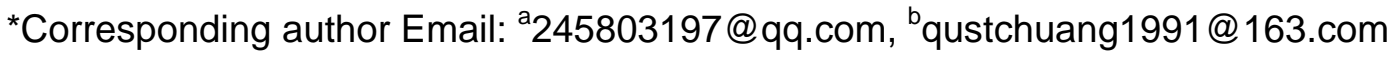

Keywords: Railway transportation equipment manufacturing, Lean production mode, Analytic Hierarchy Process, WeChat platform for secondary development.

\begin{abstract}
To evaluate the manufacturing lean production mode scientifically and objectively will help the development of it effectively, standardly and systematic, also provide strong guarantee for enhancing the competitiveness of manufacturing industry. Lean production model of manufacturing management is of great significance. By studying the content of lean production mode, then put forward the evaluation index system and set index weight method based on Analytic Hierarchy Process. Using PHP and MYSQL database to develop a mobile terminal evaluation system which based on WeChat platform. Aiming to provide business leaders with more scientific and objective evaluation of the scale of the enterprise lean production.
\end{abstract}

\section{Introduction}

With China's rapid economic development, traffic congestion, increased emissions, noise pollution and energy shortage problem has become increasingly significant, safety and convenience of public transportation are paid more attention by people. Therefore, according to series of problems of the city traffic, China needs to promote the rapid development of rail transportation equipment manufacturing industry.

However, with the rapid development of China's manufacturing industry under the market economy, the enterprise production management mode faces severe ordeal. As the scientific methods of lean production methods conform to the development of the times and can make the enterprise adapt to the change of the market, has been developing rapidly and widely used in domestic manufacturing enterprises ${ }^{[1]}$. Lean production is often seen as a set of tools that reduce the total cost and improve the quality of manufactured products ${ }^{[2]}$. But there are still relatively many problems in the implementation of lean production management, and most enterprises do not have a relatively perfect lean production model evaluation system to test and improve the implementation process of lean production in reality. Based on the analysis of the existing academic achievements of lean production evaluation and the combination of analytic hierarchy process and Delphi method, this paper establishes a lean production model evaluation system based on departmental responsibility system, The system uses the computer language compiled into micro-platform-based mobile terminal lean production mode evaluation system.

\section{Lean Production Model Evaluation Index}

Establishing a complete evaluation index system is a necessary condition for establishing a lean production evaluation system. Rail transportation equipment manufacturing enterprises are generally large enterprises, in the global market, intense competition in the environment, and gradually developed into a group enterprise ${ }^{[3]}$. So there are many factors that affect the rail transportation equipment manufacturing industry, with a multi-level structure. Through the on-site investiga-tion and study of the production sites of the group companies, the relevant information was collected, and the impact factors of the enterprises in the actual implementation of lean production management were comprehensively summarized, and the relation between the factors 
was compared one by one. Finally, the importance of each index is ranked by AHP, and the specific weight value corresponding to each evaluation index is calculated. According to the principles of departmental responsibility system, on the basis of implementing the lean production method to meet the requirements of the evaluation index of traditional lean production mode, the Delphi method, the preliminary formulation, the anonymous feedback and the iterative process. Table 1 is the final establishment of the evaluation index system.

Table 1 Lean production model evaluation index system

\begin{tabular}{|c|c|c|}
\hline First level indicator & Second level indicator & Third level indicator \\
\hline \multirow[b]{2}{*}{$\boldsymbol{B}_{1}$ Equipment department } & $\begin{array}{l}\mathbf{C}_{\mathbf{1}} \text { Equipment } \\
\text { planning }\end{array}$ & $\begin{array}{l}\boldsymbol{D}_{1} \text { Overall Equipment Effectiveness } \\
\boldsymbol{D}_{2} \text { Equipment rationalization design } \\
\text { level }\end{array}$ \\
\hline & $\mathbf{C}_{2}$ Maintenance & $\begin{array}{ll}\boldsymbol{D}_{\mathbf{3}} & \text { Equipment operating rate } \\
\boldsymbol{D}_{\mathbf{4}} & \text { Equipment movable rate } \\
\boldsymbol{D}_{\mathbf{5}} & \text { Equipment utilization rate } \\
\end{array}$ \\
\hline \multirow[b]{2}{*}{$\boldsymbol{B}_{\mathbf{2}}$ Quality department } & $\begin{array}{l}\mathbf{C}_{3} \text { Prevention and } \\
\text { control }\end{array}$ & $\begin{array}{ll}\boldsymbol{D}_{6} & \text { Quality control method system } \\
\boldsymbol{D}_{7} & \text { Exception management level } \\
\boldsymbol{D}_{\mathbf{8}} & \text { Scientific Methods for Preventing } \\
& \text { Defects } \\
\boldsymbol{D}_{\mathbf{9}} & \text { Repair rate }\end{array}$ \\
\hline & $\mathbf{C}_{4}$ Evaluation & $\begin{array}{ll}\boldsymbol{D}_{\mathbf{1 0}} & \text { First pass rate } \\
\boldsymbol{D}_{\mathbf{1 1}} & \text { Total Customer Satisfaction } \\
\boldsymbol{D}_{\mathbf{1 2}} & \text { The proportion of total loss of } \\
& \text { quality to the income from } \\
\text { main business }\end{array}$ \\
\hline \multirow[t]{2}{*}{$\boldsymbol{B}_{3}$ Logistics department } & $\mathbf{C}_{5}$ Production & $\begin{array}{ll}\boldsymbol{D}_{\mathbf{1 3}} & \text { Rationalization of distribution } \\
\text { materials } \\
\boldsymbol{D}_{\mathbf{1 4}} & \text { Logistics smooth degree } \\
\boldsymbol{D}_{\mathbf{1 5}} & \text { Equalization of Logistics } \\
\boldsymbol{D}_{\mathbf{1 6}} & \text { Rationalization of logistics } \\
& \text { layout }\end{array}$ \\
\hline & $\mathbf{C}_{6}$ Supplier & $\begin{array}{ll}D_{17} & \text { Stowage rate } \\
D_{18} & \text { Supplier delivery on time }\end{array}$ \\
\hline \multirow[t]{2}{*}{$\boldsymbol{B}_{4}$ Process department } & $\begin{array}{c}\mathbf{C}_{7} \text { Production line } \\
\text { optimization }\end{array}$ & $\begin{array}{l}\boldsymbol{D}_{\mathbf{1 9}} \text { Production line U - layout ratio } \\
\boldsymbol{D}_{\mathbf{2 0}} \text { The scientific level of the } \\
\text { process }\end{array}$ \\
\hline & $\begin{array}{l}\mathbf{C}_{\mathbf{8}} \text { Production line } \\
\text { balance }\end{array}$ & $\begin{array}{ll}\boldsymbol{D}_{21} & \text { Degree of man - machine } \\
& \text { separation } \\
\boldsymbol{D}_{22} & \text { Employee workload level } \\
\end{array}$ \\
\hline \multirow[b]{2}{*}{$\begin{array}{r}\boldsymbol{B}_{5} \text { Production } \\
\text { department }\end{array}$} & $\begin{array}{l}\mathbf{C}_{9} \text { Site management } \\
\text { and continuous } \\
\text { improvement }\end{array}$ & $\begin{array}{ll}\boldsymbol{D}_{23} & 6 \mathrm{~S} \text { management } \\
\boldsymbol{D}_{24} & \text { One Piece Flow } \\
\boldsymbol{D}_{25} & \text { Kanban management } \\
& \\
\boldsymbol{D}_{26} & \text { Production site safety level } \\
\boldsymbol{D}_{27} & \text { Visual management } \\
\end{array}$ \\
\hline & & $\begin{array}{ll}\boldsymbol{D}_{28} & \text { Standard job sequence } \\
\boldsymbol{D}_{29} & \text { Standard WIP inventory }\end{array}$ \\
\hline
\end{tabular}




\begin{tabular}{|c|c|c|}
\hline & $\mathbf{C}_{\mathbf{1 0}}$ Standard Operation & $\begin{array}{l}\boldsymbol{D}_{30} \text { The settings for the timer point } \\
\boldsymbol{D}_{31} \text { Job repeatability } \\
\boldsymbol{D}_{32} \text { Job Standard Coverage } \\
\boldsymbol{D}_{33} \text { Feature Job Time } \\
\boldsymbol{D}_{34} \text { Assign workload by beat }\end{array}$ \\
\hline \multirow{3}{*}{$\begin{array}{c}\boldsymbol{B}_{6} \text { Human resources } \\
\text { department }\end{array}$} & $\begin{array}{c}\mathbf{C}_{\mathbf{1 1}} \text { Training and } \\
\text { education }\end{array}$ & $\begin{array}{ll}\boldsymbol{D}_{35} & \text { Personnel training system } \\
\boldsymbol{D}_{36} & \text { Personnel assessment system } \\
\boldsymbol{D}_{\mathbf{3 7}} & \begin{array}{l}\text { Skill evaluation method of } \\
\text { rationalization level }\end{array} \\
\boldsymbol{D}_{38} & \text { Multi - skill level } \\
\boldsymbol{D}_{39} & \text { Annual per capita training hours }\end{array}$ \\
\hline & $\mathbf{C}_{\mathbf{1 2}}$ teamwork & $\begin{array}{l}\boldsymbol{D}_{\mathbf{4 0}} \text { Number of team members } \\
\boldsymbol{D}_{\mathbf{4 1}} \text { Skills complementarity } \\
\boldsymbol{D}_{\mathbf{4 2}} \text { The prestige of the team leader }\end{array}$ \\
\hline & $\begin{array}{l}\mathbf{C}_{13} \text { Morale and mental } \\
\text { outlook }\end{array}$ & $\begin{array}{l}\boldsymbol{D}_{\mathbf{4 3}} \text { Rationalization proposals } \\
\boldsymbol{D}_{\mathbf{4 4}} \text { Rationalization proposal } \\
\text { adoption rate } \\
\boldsymbol{D}_{\mathbf{4 5}} \text { Reward and punishment system } \\
\boldsymbol{D}_{\mathbf{4 6}} \text { QC group and other activities } \\
\text { carried out }\end{array}$ \\
\hline
\end{tabular}

The index system for the model index system, each evaluation can be based on this system, according to the corresponding evaluation of the different objectives of the appropriate focus on the increase and deletion.

\section{Lean Production Model Evaluation Method}

In recent years, with the domestic and international mathematics and applied mathematics in different areas of the development of mature, comprehensive evaluation of practice in the system has obvious results. At present, there are many kinds of comprehensive evaluation methods, such as principal component analysis, analytic hierarchy process, clustering analysis, fuzzy comprehensive evaluation and so on ${ }^{[4]}$. Which method is used to calculate the weight value of the indicator depends 
on the characteristics of the method and the characteristics and contents of the evaluation system. Lean production model evaluation is a multi-objective index system composed of several factors, which is multi-level and complicated. Therefore, using the analytic hierarchy process, this method has the consistency of testing links, can reduce the subjective influence of the expert group to the greatest extent, and have the role of unified view ${ }^{[5]}$. Specific steps are as follows:

(1) build the judgment matrix

Assuming the establishment of rail transportation equipment manufacturing lean production model evaluation index system for the target level A, First level indicators for the department level $\mathrm{B}$, the second level indicators for the responsibility level $\mathrm{C}$, the third level indicators for the index level $\mathrm{D}$, the structure of the judgment matrix is generally taken as shown in Table 2.

Table 2 the form of the judgment matrix

(2) hierarchical single sort

\begin{tabular}{c|cccc}
$\mathrm{A}$ & $\mathbf{B}_{1}$ & $\mathbf{B}_{2}$ & $\ldots$ & $\mathbf{B}_{n}$ \\
\hline $\mathbf{B}_{1}$ & $\mathrm{~b}_{11}$ & $\mathrm{~b}_{12}$ & $\ldots$ & $\mathrm{b}_{1 n}$ \\
$\mathbf{B}_{2}$ & $\mathbf{b}_{21}$ & $\mathrm{~b}_{22}$ & $\ldots$ & $\mathrm{b}_{2 n}$ \\
$\cdot$ & $\cdot$ & $\cdot$ & $\ldots$ & $\cdot$ \\
$\cdot$ & $\cdot$ & $\cdot$ & $\ldots$ & $\cdot$ \\
$\cdot$ & $\cdot$ & $\cdot$ & $\ldots$ & $\cdot$ \\
$\mathbf{B}_{n}$ & $\mathbf{b}_{n 1}$ & $\mathrm{~b}_{n 2}$ & $\ldots$ & $\mathrm{b}_{n n}$
\end{tabular}

The largest eigenvalue of the judgment matrix $\lambda_{\max }$ and the corresponding eigenvector $\omega$ are calculated by square root method.

$$
\mathrm{B} \omega=\lambda \omega
$$

The obtained vector is normalized, and the resulting vector value is the weight value of the corresponding factor of the same level to the relative importance of the corresponding factor of the previous layer, By multiplying by one, the relative importance index weights for each sector relative to total objective A can be calculated.

(3) consistency of the single-level test

Random Consistency Ratio

$$
\mathrm{CR}=\frac{C I}{R I}
$$

When $\mathrm{CR}<0.1^{[6]}$, Then the results of the hierarchical single sort have satisfactory consistency, otherwise the elements of the judgment matrix need to be adjusted. Among them, the consistency index:

$$
\mathrm{CI}=\frac{\lambda_{\max }-n}{n-1}
$$

The value of the average randomness consistency index RI has different fixed values according to the judgment matrix of 1-9 order, as shown in Table 3.

Table 3 RI value table

\begin{tabular}{c|c|c|c|c|c|c|c|c}
\hline 1 & 2 & 3 & 4 & 5 & 6 & 7 & 8 & 9 \\
\hline 0.00 & 0.00 & 0.58 & 0.90 & 1.12 & 1.24 & 1.32 & 1.41 & 1.45 \\
\hline
\end{tabular}

By calculation, $\mathrm{CI}<0.1$. The calculated index values have satisfactory consistency. Table 4 shows the index weights of each level relative to the previous level.

Table 4 The weight of each indicator

\begin{tabular}{c|c|c|c|c|c|c|c}
\hline Level B & $\mathrm{B}$ & $\mathrm{B}_{1}$ & $\mathrm{~B}_{2}$ & $\mathrm{~B}_{3}$ & $\mathbf{B}_{4}$ & $\mathbf{B}_{5}$ & $\mathrm{~B}_{6}$ \\
\hline indicator & 1 & $1 / 6$ & $1 / 6$ & $1 / 6$ & $1 / 6$ & $1 / 6$ & $1 / 6$ \\
\hline
\end{tabular}

\begin{tabular}{c|c|c|c|c|c|c|c}
\hline Level C & $\mathbf{C}_{\mathbf{1}}$ & $\mathbf{C}_{\mathbf{2}}$ & $\mathbf{C}_{\mathbf{3}}$ & $\mathbf{C}_{\mathbf{4}}$ & $\mathbf{C}_{\mathbf{5}}$ & $\mathbf{C}_{\mathbf{6}}$ & $\mathbf{C}_{\mathbf{7}}$ \\
\hline indicator & 0.25 & 0.75 & 0.75 & 0.25 & 0.5 & 0.5 & 0.5 \\
\hline Level C & $\mathrm{C}_{8}$ & $\mathrm{C}_{9}$ & $\mathrm{C}_{10}$ & $\mathrm{C}_{11}$ & $\mathrm{C}_{12}$ & $\mathrm{C}_{13}$ & \\
\hline indicator & 0.5 & 0.25 & 0.75 & 0.5842 & 0.2808 & 0.1350 & \\
\hline
\end{tabular}




\begin{tabular}{c|c|c|c|c|c|c|c}
\hline $\mathrm{D}_{1}$ & $\mathrm{D}_{2}$ & $\mathrm{D}_{3}$ & $\mathrm{D}_{4}$ & $\mathrm{D}_{5}$ & $\mathrm{D}_{6}$ & $\mathrm{D}_{7}$ & $\mathrm{D}_{8}$ \\
\hline 0.5000 & 0.5000 & 0.6000 & 0.2000 & 0.2000 & 0.4799 & 0.1215 & 0.1215 \\
\hline $\mathrm{D}_{9}$ & $\mathrm{D}_{10}$ & $\mathrm{D}_{11}$ & $\mathrm{D}_{12}$ & $\mathrm{D}_{13}$ & $\mathrm{D}_{14}$ & $\mathrm{D}_{15}$ & $\mathrm{D}_{16}$ \\
\hline 0.2771 & 0.3196 & 0.5584 & 0.1220 & 0.1051 & 0.1644 & 0.4457 & 0.2848 \\
\hline $\mathrm{D}_{17}$ & $\mathrm{D}_{18}$ & $\mathrm{D}_{19}$ & $\mathrm{D}_{20}$ & $\mathrm{D}_{21}$ & $\mathrm{D}_{22}$ & $\mathrm{D}_{23}$ & $\mathrm{D}_{24}$ \\
\hline 0.6667 & 0.3333 & 0.3333 & 0.6667 & 0.6667 & 0.3333 & 0.0522 & 0.3499 \\
\hline $\mathrm{D}_{25}$ & $\mathrm{D}_{26}$ & $\mathrm{D}_{27}$ & $\mathrm{D}_{28}$ & $\mathrm{D}_{29}$ & $\mathrm{D}_{30}$ & $\mathrm{D}_{31}$ & $\mathrm{D}_{32}$ \\
\hline 0.1104 & 0.3706 & 0.1169 & 0.0542 & 0.1693 & 0.0660 & 0.1693 & 0.2317 \\
\hline $\mathrm{D}_{33}$ & $\mathrm{D}_{34}$ & $\mathrm{D}_{35}$ & $\mathrm{D}_{36}$ & $\mathrm{D}_{37}$ & $\mathrm{D}_{38}$ & $\mathrm{D}_{39}$ & $\mathrm{D}_{40}$ \\
\hline 0.0818 & 0.2278 & 0.2721 & 0.1753 & 0.1408 & 0.3390 & 0.0728 & 0.1350 \\
\hline $\mathrm{D}_{41}$ & $\mathrm{D}_{42}$ & $\mathrm{D}_{43}$ & $\mathrm{D}_{44}$ & $\mathrm{D}_{45}$ & $\mathrm{D}_{46}$ & & \\
\hline 0.5842 & 0.2808 & 0.3715 & 0.3715 & 0.0941 & 0.1629 & & \\
\hline
\end{tabular}

(4) the evaluation of comprehensive evaluation of the score

According to the evaluation index in Table 1, The evaluation criteria of each index of level D are excellent, good, medium and poor, the corresponding scores were 100,85,60,40, So if an indicator score of the level $\mathrm{D}$ is 85 points, then this indicator for the total weight of the target $\mathrm{A}$ is multiplied by 85 .

\section{Mobile Terminal Evaluation System Based on Micro Message Platform}

Relative to the computer, Mobile phone has the advantages of easy to carry. You can online at any time any place and will not be constraint by time and place. In recent year, with the use of smart phones to reduce the threshold, almost a staff of a mobile phone. As a feature-rich mobile phone applications, WeChat has a huge number of users. At the same time, WeChat public platform has a rich application interface for developers to call, which provides a good way to develop mobile micro-applications. And the WeChat platform, with the advantages relative to the APP, is not limited to the mobile phone operating system and do not need to develop the appropriate architecture for different systems.

Evaluation system uses PHP language, the application of MYSQL database for data management. Figure 1 is the storage of primary and secondary indicators of the data sheet. The use of HTML5 display page and realize the function, the system used in the INTERNET network environment, Figure 2 shows the system interface. System docks the WeChat platform. In addition to self-evaluation function, the WeChat platform can regularly collect industry information and subscription to the user regularly. Users can query and browse knowledge of the lean production and rail on the public platform, It saves time searching for data on the Internet. WeChat platform interface is shown in Figure 3. 


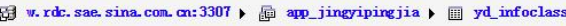

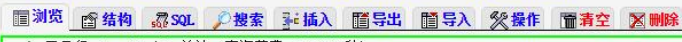

$\checkmark$ 显示行 $0-18$ (19 总计, 查询花费 0.0011 秒)

SRIBCT *
FROAl
Ydinfoclass

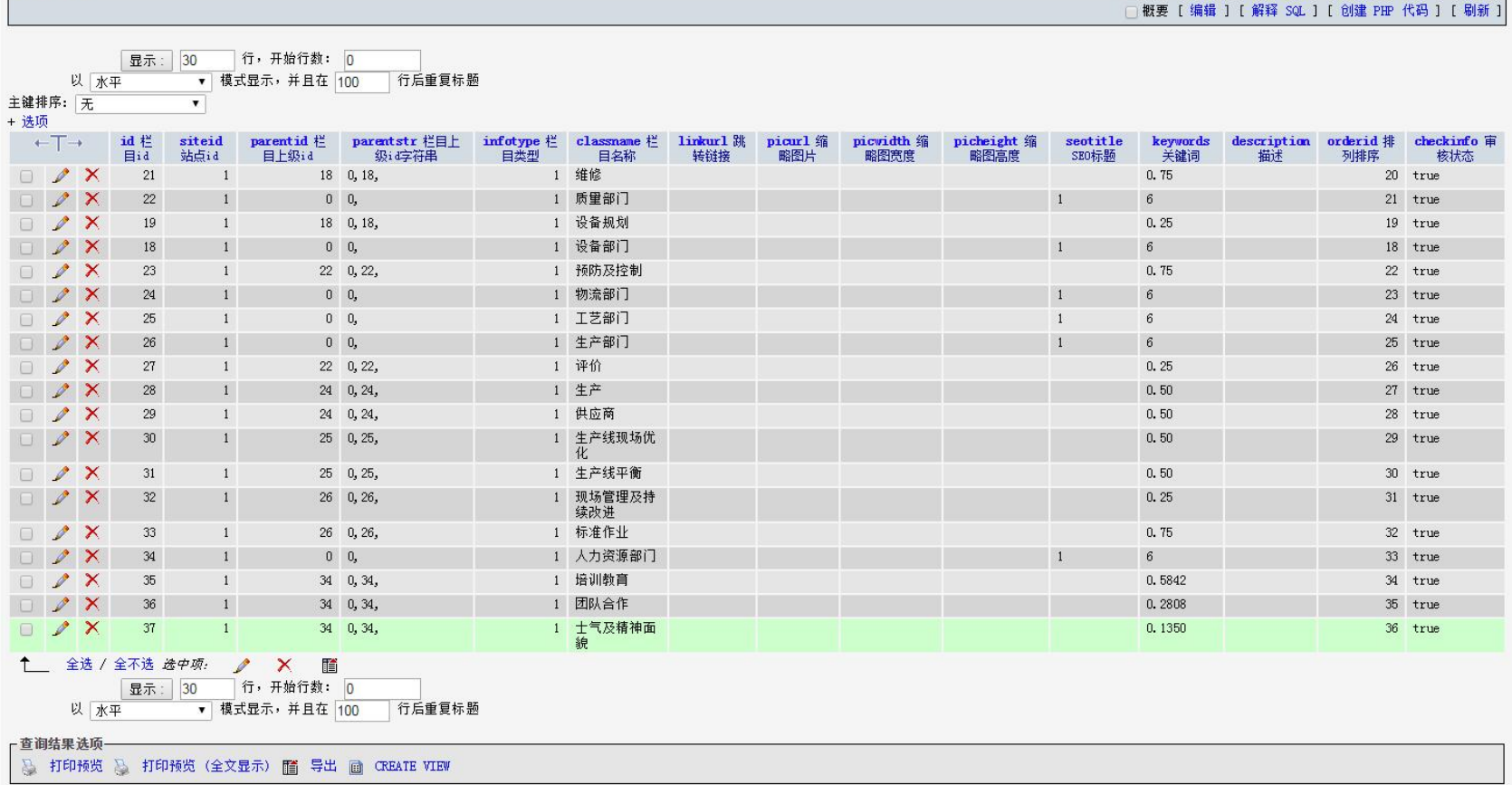

3 打印预览 8 打印预览 (全文显示) 算 导出 画 CREATE VIEU

\section{$\times \quad$ 精益生产模式评价指标体系}

\section{粗益生产模式评价提标体聚}

一. 设备规划

1. 设各合理化设计水平 *

- 优

皮

中心

至

2. 设备综合效率

○ 优

B2

中等

童

下一娄

Figure 2 Evaluation index system
Figure 1 Data sheet

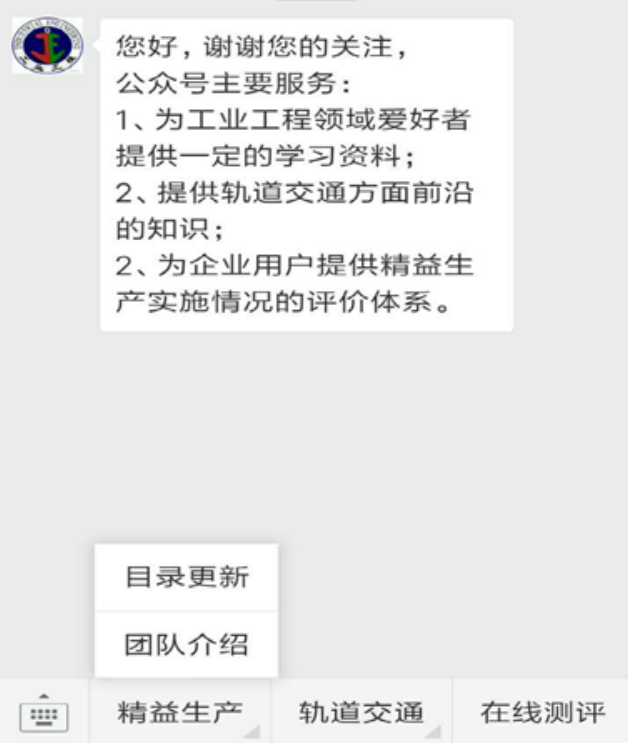

Figure 3 WeChat public platform interface

\section{Summary}

According to on-the-spot investigation and study in the rail transportation equipment manufacturing enterprise, depth research on the lean production of enterprises and combined with lean production and process management and other related theories. This paper establishes a set of evaluation index system for evaluating lean manufacturing mode of rail transportation equipment manufacturing enterprises. On this basis, the Delphi method and analytic hierarchy process are used to determine the weight of the index, and the mobile terminal evaluation system based on the WeChat platform is designed. It can improve the level of lean production in the rail transportation equipment manufacturing enterprises .And has a good demonstration effect on lean manufacturing evaluation of manufacturing industry. 


\section{References}

[1] Huiling Luan. Research on lean production evaluation system of small and medium sized enterprises based on data envelopment analysis [D] .Shenyang University of Technology.

[2] R.M.Torielli, R.A.Abrahams, R.V.Smillie and R.C.Voigt. Using lean methodologies for economically and environmentally sustainable foundries. China Foundry, 2011:74-75

[3] Yongcai Sun, Xiulun Wang, Ziqin Ma. Research on contemporary technology and process management level evaluation of railway transportation equipments manufacture[J].Railway Locomotive\&Car

[4] Yang Qi, Ying Wang. Research on the spatial layout of China's equipment manufacturing industry competitiveness evaluation[J]. Inquiry into Economic Issues.

[5] Zhidong Shen. Analysis of analytic hierarchy process to build a state-owned enterprises evaluation system[J].Auditing Research.

[6] Huanchen Zhao, Shubai Xu, Jinsheng He. Analytic Hierarchy Process[M].Science press. 